\title{
DOCUMENTO
}

\section{Si quieres promover la paz, protege la creación}

Éste es el título del mensaje del Papa para la Jornada mundial de la paz de 1 de enero de 2010. En otras ocasiones RFS ha publicado el texto íntegro del mensaje. ' Este año iniciamos una nueva forma de traer a nuestra revista éste y otros documentos, cuando se trate de textos en versión castellana fácilmente accesibles por internet. Hacemos una breve presentación del mismo y damos la referencia para el acceso informático: www.vatican.va/holy father/benedict xvi/messages/ peace/documents.

El mensaje de 2010 plantea una toma de conciencia sobre la relación estrecha que en nuestro mundo globalizado existe entre la protección de la naturaleza y la convivencia pacífica de la humanidad. En la última encíclica sobre el desarrollo humano e integral en la caridad y en la verdad se pone de relieve la relación entre el hombre con el entorno natural y desarrollo. Esta relación concierne al uso de los recursos naturales, a los cambios climáticos, a la biotecnología aplicada o al crecimiento demográfico. Ya en 1971 Pablo VI se refería a la conciencia ecológica y en 1990 Juan Pablo habló sobre la crisis ecológica y la necesidad de una nueva solidaridad. La familia humana ha de reforzar y renovar la alianza entre el ser humano y el entorno. Entre otras cuestiones, el mensaje propone las siguientes: ¿cómo olvidar el fenómeno creciente de los llamados "refugiados ambientales"? ¿̇ómo no reaccionar ante los conflictos reales o potenciales que derivan del acceso a los recursos naturales? Si la familia humana no afronta una revisión profunda cultural y moral del modelo de desarrollo así como estos desafíos con renovado sentido de la justicia social, de la solidaridad internacional o global (mensaje de 2009) y de la solidaridad intergeneracional, se corre el riesgo de sembrar violencia entre los pueblos y entre las generaciones presentes y futuras. El mensaje llama la atención sobre la distorsión que se ha hecho de las palabras

' La última fue el año en curso: "Mensaje para la celebración de la Jornada mundial de la Paz, 1 de enero de 2009: Combatir la pobreza, construir la paz": Revista de Fomento Social 64 (2009) 131-140. 
del Génesis del encargo de "dominar" la tierra y pone en relación la protección de la creación con el derecho de propiedad y el destino universal de los bienes. Por ello la cuestión ecológica no debe sólo ser afrontada desde la perspectiva de la degradación ambiental, sino que debe ser un motivo serio para cultivar la paz. Existen oportunidades científicas y potenciales vías innovadoras técnicas para una "nueva solidaridad" y una "solidaridad global". Esta responsabilidad ecológica no es indiferente a nuestra comprensión de "ecología humana", aspecto al que también se refiere la citada encíclica Caritas in veritate, así como ha de discernir ante visiones ecocentristas y biocentristas. La Iglesia invita a plantear la cuestión de la conservación de la creación de manera equilibrada, desde la virtud de la prudencia y desde el respeto a la "gramática» de aquélla y de su fundamento teologal. [Redacción de RFS] 